\title{
INFLUENCE OF HABITAT PARAMETERS ON COMMON SKIPPER FROG (EUPHLYCTIS CYANOPHLYCTIS) IN CHITTAGONG
}

\author{
Mohammad Abdul Wahed Chowdhury*, Md. Mizanur Rahman \\ and Md. Abdul Gofur Khan \\ Department of Zoology, University of Chittagong, Chittagong 4331, Bangladesh
}

\begin{abstract}
Habitat selection of common skipper frog [Euphlyctis cyanophlyctis (Schneider, 1799)] was studied by a sampling (covering all the three seasons) of data collection on six abiotic (size and depth of water body, air and water temperature, dissolved oxygen and free carbon dioxide) and three biotic (plant species richness, zooplankton species richness and zooplankton density) factors of three ponds in Chittagong, Bangladesh. The discriminant analysis, cluster analysis and paired t-test of total data revealed that the three water bodies functioned as separate systems. Of the nine factors, only four (AT, WT, $\mathrm{FCO}_{2}$ and $Z$ p_den) had individual significant influence on the frog at least at one of the ponds. However, the maximum $\mathrm{R}^{2}$ value $(0.712, \mathrm{p}<0.001)$ indicates that at least some important factors were not included in the investigation.
\end{abstract}

Key words: Habitat factor, factor interaction, population ecology, Euphlyctis cyanophlyctis

\section{INTRODUCTION}

Amphibians are the only vertebrate with a biphasic life cycle (Stuart et al. 2004), having to shift obligatorily during the metamorphosis from an aquatic larval stage to a terrestrial adult life (Pough 2004). Unfortunately, globally anuran populations are declining due to wide varieties of reasons, e.g., habitat loss and fragmentation, global environmental changes, proximate causes as emerging infectious diseases (Blaustein et al. 1994, Gibbons et al. 2000, Stuart et al. 2004), exotic species, ultraviolet radiation and environmental contaminants (Blaustein and Kiesecker 2002), etc. Although these causes are probably interacting synergistically, habitat degradation is considered by most amphibian ecologists to be the primary cause of this decline (Alford and Richards 1999).

Recent publications reported 34 to 49 anuran species of seven families from Bangladesh (Asmat and Hannan 2007, Kabir et al. 2009, Hasan et al. 2014). Very few of those work dealt with in depth analysis of their ecological relationships. Understanding habitat requirements and habitat use of amphibians are major challenges in their conservation (Marsh et al. 1999, Harlet et al. 2006). Habitat selection of anurans is known to be influenced by environmental factors, like the abiotic temperature and $\mathrm{pH}$ (Banks and Beebee,

*Corresponding author: wahed.chowdhury@cu.ac.bd

(C) 2016 Zoological Society of Bangladesh DOI: 10.3329/bjz.v44i1.30183 
1987, Pope et al. 2000), and the biotic like the competitors, predators, and the degree to which resources are distributed spatially (Crump 1991, Daniels 1992, Nie et al. 1999, Lin et al. 2008, Indermur et al. 2009). Very recently, Akram et al. (2015) worked on the influence of some abiotic and biotic factors on the habitat selection of some anurans in Pakistan and Lemckert (2006) worked on the correlation between frogs and pond attributes in Australia. In Bangladesh, similar works are limited to only one publication by Chowdhury and Das (2014), and two unpublished research project (Das 2013, Shil 2014).

The common skipper frog (Euphlyctis cyanophlyctis) is a common species in littoral part of both lentic and lotic waters (Gaston et al. 1997, Pyron 1999, Inger 1999, Das 2008). This species also occurs in estuarine waters of various countries (Daniel 2002, Lalremsanga 2012). In Bangladesh, it is a common species of both lentic (even of forest water bodies of modest altitude) and lotic waters (creeks and streams of fresh and saline water) (Chakma 2009, personal observation at Moheshkhali and Nijhum Dwip - two islands of Bangladesh). The state of present knowledge on this frog is that the estuarine specimens will possibly be a separate species (Khan 1997, Alam et al. 2008, Joshy et al. 2009). In view of its euryecious nature, the present work on the habitat ecology of only the fresh water specimens was undertaken.

\section{MATERIAL AND METHODS}

The Chittagong University Campus (CUC) (between 22 27'25.69" and

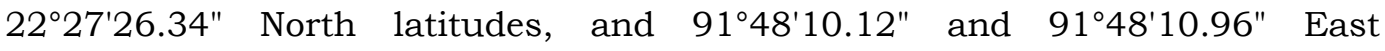
longitudes) is situated in over 1754 acres hilly area (Chowdhury and Das 2014). The campus area, due to high elevation, was never affected by flooding. However, the campus has a good number of small perennial lakes and ponds, and several narrow hilly streams. The neighbouring lands of those water bodies frequently turned into temporary wetland because of comparatively greater amounts of rain characteristics of CUC. The summer extends from March to May, and is characterized by dry hot condition interrupted by occasional rains with north western storms and prevailing winds from the south west (Islam et al. 1979). The monsoon, last from June to October, is humid and warm, with infrequent thunder storms, with high temperature and wind from the southeast; about $90 \%$ of the annual rainfall occurs during this season (Islam et al. 1979). The winter season, exist between November and February, is cold and dry with prevailing winds from the north-west, rainfall and humidity are lowest during this part of the year.

Three study sites, with different extents of variations in habitat, were chosen considering, also, size, location and availability of frogs. 
Site 1 ( $\mathrm{S} 1)$, the Science Faculty Lake, is a moderately large (2 acres) perennial water body with an average depth of $0.97 \mathrm{~m}$. Floating and submerged aquatic weeds have luxuriant growth in this lake.

Site 2 (S2), the Round Pond, is also a perennial water body with an area of 0.59 acre and a mean depth of $1.9 \mathrm{~m}$. It is frequently used for swimming practice. Due to high banks, runoff water does not enter this pond (Khan et al. 2007). The shallow parts support lots of hydrophytes facilitating frog community to inhabit and seek shelter and food.

Site 3 (S3), the Forestry Lake, is characterized by an almost flat basin, banks with the gentle slope, and hills on two sides. Total area of the water body is about 1.5 acres, and its mean depth is $1.1 \mathrm{~m}$. The hill slopes have many planted teak trees. The physico-chemical conditions of S1 and S3 are significantly influenced by drainage from the hilly watersheds. Site 1 , however, has additional problem from drainage from the laboratories of science departments.

Habitat selection of Euphlyctis cyanophlyctis (henceforth abbreviated as Ec) was investigated in relation to six abiotic factors, viz., size and depth of water body, air and water temperature (AT and WT), dissolved oxygen (DO), free carbon dioxide $\left(\mathrm{FCO}_{2}\right)$ and three biotic factors, viz., plant species richness (PSR), zooplankton species richness (ZSR) and zooplankton density (Zp_den) of three aforementioned water bodies of the CUC. From earlier knowledge and preliminary investigations it is known that $E c$ is active throughout the year. The study period, extends three practical seasons (summer, rainy and winter) (Ahmed 1968) of Bangladesh, was decided in view of the knowledge that this time includes the pre-breeding and post-breeding periods of the frog species. The study plan was based on collecting data on frogs (young to adult) and the ecological factors. The sampling months were January (mid winter), February (late winter), March (early summer), April (mid summer), August (mid rainy season) and September (late rainy season). Data were collected almost systematic random fashion with minimum six days interval. On each sampling day, recording of ecological factors of the three water bodies was completed between 0800 and $1200 \mathrm{hrs}$; whereas data on the frogs were taken on the same day between 1900 and 2300 hrs. The night sampling time for the frog data was decided in view of the concealing habitat of the frogs under vegetation cover. Light and sound disturbance was kept at minimum possible level for the same reason (Declining Amphibian Population Task Force 2001, ASIH 2004). The numerical data on the frogs were recorded studying 8-10 stratified sampled quadrates $(1 \mathrm{~m} \times 1 \mathrm{~m})$ from each of the three water bodies. Field notes were taken in a standardized form adopted from Lips et al. (2001). The frog specimens were identified using morphological characters provided by Günther (1864), Boulenger (1890) and with the help of some recent research, viz., Balletto et al. 
1985, Ford and Cannatella 1993, Dubois and Ohler 1995, Das and Dutta 1998, Chowdhury 2009). Breeding activities (copulation, foaming, tadpoles, etc.) were observed during breeding seasons but not included in this study, only adults available at a site have been considered for present research.

Temperature was measured instantly by using the mercury thermometer calibrated from 0 to $110^{\circ} \mathrm{C}$. Water depth and size were, also instantly, measured by using rope and measuring tape in meter scale. Dissolved oxygen and free carbon dioxide were measured, in the laboratory, by Winkler Modification of the Azide Method and Titrimetric Method, respectively (APHA 2005). The zooplankton analysis was carried out using Sedgwick Rafter counting Cell (APHA 2005). All statistical analyses were done using the SPSS version 17.0. Canonical Discriminant Analysis of the data matrix $(10 \times 51[\mathrm{n}=17 \times 3$ sites $])$ necessitated further correlations and regressions analyses done separately for each of the water bodies.

\section{RESULTS AND DISCUSSION}

An investigation was carried out to study the influence of nine environmental factors, mainly physico-chemical, on the habitat ecology of common skipper frog (Euphlyctis cyanophlyctis) of three water bodies of the Chittagong University Campus. Of the nine factors, seven fluctuated temporarily, hence designated as dynamic; the values of the rest two factors, Size and PSR, did not vary over time - thus were static. The data of the four dynamic factors and of the frog varied significantly among the sites ( $F$ values, Table 1 ). Canonical discriminant analysis (Fig. 1), cluster analysis, and paired t-test of total data of the three sites also made evident that each of them functioned as separate system, for which data analyses were carried out separately for the sites (ponds). The close proximity of the sites, situated within $2 \mathrm{~km}$, might have caused some of their physicochemical parameters almost not fluctuating spatially, but differences in size and depth, topography and landscape, and light related effects, etc., which were not recorded in present study, possibly made each site operating as a unique system (Khan et al. 2007, Islam et al. 1979).

Size wise the ponds were of the following sequence - S1 $\left(8093.7 \mathrm{~m}^{2}\right)>\mathrm{S} 3$ $\left(6070.28 \mathrm{~m}^{2}\right)>\mathrm{S} 2\left(2375.8 \mathrm{~m}^{2}\right)$. Depth wise the sequence was, however, different - S2 (range 1.49-2.37, mean $1.85 \pm \mathrm{Sd} 0.41 \mathrm{~m})>\mathrm{S} 3(0.81-1.49,1.10 \pm 0.30 \mathrm{~m})>$ $\mathrm{S} 1(0.42-1.75,0.97 \pm 0.60 \mathrm{~m})$ (Table 1). In all, 23 plant species were recorded in the margin of the ponds and part of the banks affected by water level fluctuations - the plant species number was roughly similar among the ponds 13, 15 and 16, respectively for S1, S2, and S3 (Table 1). The densities of the plants of the ponds were apparently, from eye estimation, similar (Das, 2013, Shil 2014). 


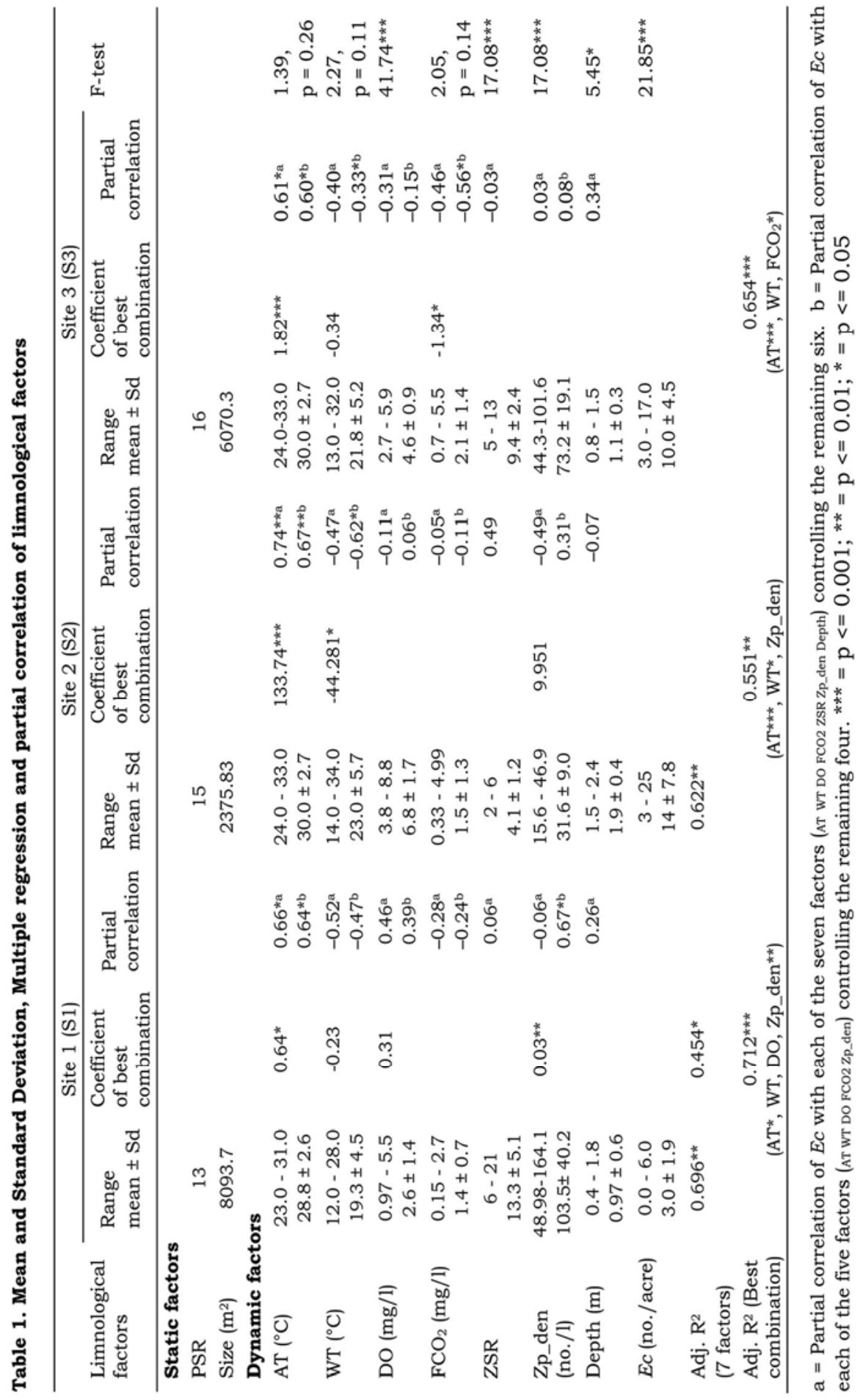


The differences between AT $\left(23-33^{\circ} \mathrm{C}\right)$ and WT $\left(12-34^{\circ} \mathrm{C}\right)$ data was as expected, did not differ significantly, among the ponds (Table 1). However, the unusual wider range of WT, than that of AT, reasonably resulted from the limitation of the study period (January - April and August - September, 2014). The dissolved oxygen concentration (DO), considered the most important limnological parameter (UNESCO/WHO 1978), differed significantly among the three sites $\left(\mathrm{F}=41.74^{* * *}\right)$. The concentrations $(\mathrm{mg} / \mathrm{l})$ of this parameter ranged $3.83-8.75$, mean $6.83 \pm \mathrm{Sd} 1.65$ at S2; $2.70-5.90,4.62 \pm 0.86$ at $\mathrm{S} 3$, and 0.97 - 5.50, $2.62 \pm 1.40$ at S1. The highest value at S2 is consistent with the water quality, depth (deepest among the three), poor organic matter (Khan et al. 2007)

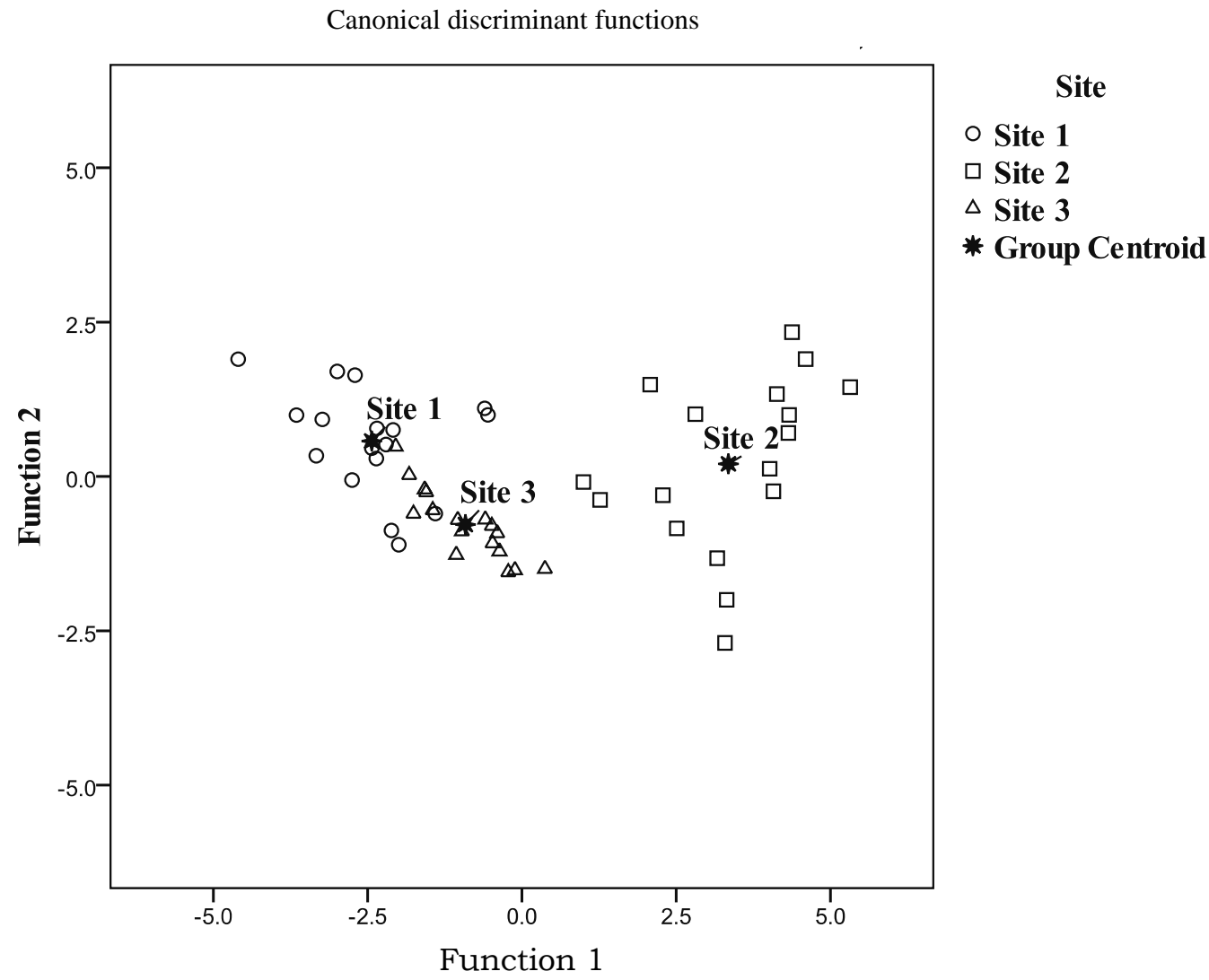

Fig. 1. The discriminant analysis of factors of the three sites.

in water, and, above all, the much higher abundance of Ec at the site. The lowest DO concentration was obtained at S1 which is virtually a hyper polluted (water colour is, generally, dark brown, indicating abundance of humic matter) and almost dead water body (Das, 2013; Shil, 2014). It is almost dry except for 
the rainy season; rooted macrophytes (both submerged and emerging) have engulfed the water body. S3 has a medium area and depth, and also a moderate DO concentration. This long, narrow and roughly rectangular water body is closed to domestic use. Apparently, it has got a medium water quality, indicated by water colour. It should be mentioned here that water colour indicates many things regarding limnological condition including trophic state (Wetzel 1975).

On the other hand, the $\mathrm{FCO}_{2}$ values $(\mathrm{mg} / \mathrm{l})$ were almost similarly low, at all the three ponds (mean $1.38 \pm \mathrm{Sd} 0.68$ at $\mathrm{S} 1,1.53 \pm 1.30$ at $\mathrm{S} 2$, and $2.13 \pm 1.36$ at S3). This similarity of the parameter in the three ponds is, however, inconsistent with the differences of the water bodies as evident from the other limnological parameters - an interesting matter justifying further investigations on this aspect.

Both species richness and density of zooplankton (no./1) were the highest in $\mathrm{S} 1(21,103.53 \pm 40.19)$; S3 had the medium values $(13,73.21 \pm 19.06)$, while at S2 both values were the least (Table 1). The SR values of zooplankton were not consistent with the apparent water qualities of the water bodies, which indicate interesting possibilities that should be investigated. However, the SR and density were absolutely correlated in each of the three ponds $\left(\mathbf{r}_{\text {ZSR Zp_den }}=1.00^{* * *}\right.$ in $\mathrm{S} 1, \mathrm{~S} 2$ and $\mathrm{S} 3)$.

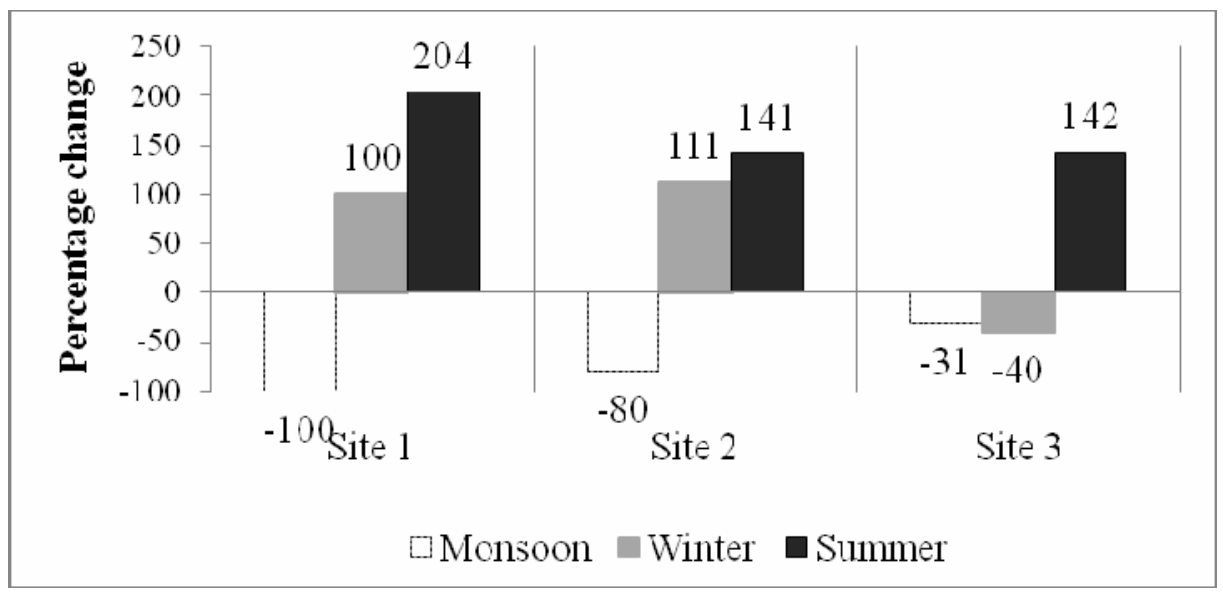

Fig. 2. Percentage change of seasonal fluctuations of $E c$ population with respect to the population size of the preceding season at the three sites.

The population of E. cyanophlyctis: The density of E. cyanophlyctis differed significantly at the three sites $\left(\mathrm{F}=21.85^{* * *}\right.$, Table 1$)$. The density was higher at S2 (14 \pm 7.83 per acre); values for S3 and S1 were lower, $10.00 \pm 4.49$ and 3.00 \pm 1.90 , respectively. Shil (2014) in another study on these ponds found similar pattern of fluctuations of Ec. The high value of standard deviation of $E c$, as also 
observed by Shil (2014), indicated the wide fluctuation pattern of this species in all sites.

The occurrence of $E c$ decreased in all three sites in the monsoon (Rainy season) from that of the summer (hot and wet); it increased in the winter (cold and dry) only at S1 and S2, and then reached the peak at all sites during the summer (Fig. 2). This notable increase was due to the flocking, possibly a nature of the frog, after the first showers of the year in end part of the winter.

Habitat ecology: As mentioned earlier, analysis of data was carried out separately for the ponds, because of the inference derivable from discriminant analysis and cluster analysis. The significance of the differences in the mean values of eight dynamic variables of the three sites was tested by Paired t-test, which also agrees fully with the conclusion derived from discriminant and cluster analyses. Size and PSR were automatically dropped, by default, in the subsequent analytic methods, as they were not varying (therefore static), having, hence, no influence on the dependent variable $(E c)$.

Analysis of influence of the independent variables on the frog populations of the three sites revealed that five variables, viz., AT, WT, DO, $\mathrm{FCO}_{2}$, and $\mathrm{Zp}$ _den were the influential factors. Individually, AT was significantly influential, in both multiple regression and partial correlation, in all the three sites, whereas $\mathrm{Zp}$ _den, WT and $\mathrm{FCO}_{2}$ were each influential in only one of the three sites - S1, S2 and S3, respectively. Although, the DO was present in every significant combination of factors affecting $E c$ in all the sites, it was never individually influential. The combined influences of those five factors were, however, different among the sites $-70.3 \%(\mathrm{p}<0.01)$ at $\mathrm{S} 1,47.7 \%(\mathrm{p}<0.05)$ at $\mathrm{S} 2$ and $60.4 \%(\mathrm{p}<$ $0.01)$ at $\mathrm{S} 3$.

The following equations from regression analysis indicate higher combined influences of some of the variables, supporting the earlier conclusion that the sites functioned independently, and also showing the phenomenon of factor interactions accountable, at least partly, for the varied influences on the frog species (Table 1).

$$
\begin{aligned}
& \mathrm{R}^{2}=0.712^{* * *}\left(\mathrm{AT}^{*}, \mathrm{WT}, \mathrm{DO}, \mathrm{Zp} \_\right. \text {den } \\
& \\
& \left.\mathrm{R}^{2 *}\right) \text { in } \mathrm{S} 1 \\
& \mathrm{R}^{2}=0.551^{* *}\left(\mathrm{AT}^{* * *}, \mathrm{WT}^{*}, \mathrm{Zp} \text { _den }\right) \text { in } \mathrm{S} 2 \\
& \text { (AT }
\end{aligned}
$$

In view of the direct dependence of WT on AT (Sharma and Kumar, 2002) $\left(\mathbf{r}_{\text {AT WT }}=0.835^{* * *}\right.$ at S1; $\mathbf{r}_{\text {AT WT }}=0.794^{* * *}$ at S2 and $\mathbf{r}_{\text {AT WT }}=0.799^{* * *}$ at S3), and in view of the positive correlation between $\mathrm{AT}$ and $E c$ at all the sites, the relationship between WT and Ec was deviatory. The influence of WT on Ec was significant only at $\mathrm{S} 2$, that too negatively (eqs. 4, 5 and 6).

$\mathbf{r}_{E c \text { WT }}$ AT DO FCO2 Z Z_den $=-0.469$ in $\mathrm{S} 1$ 


$$
\begin{aligned}
& \mathbf{r}_{E c \text { WT }} \text { AT DO FCO2 Zp_den }=-0.622 * \text { in } \mathrm{S} 2 \\
& \mathbf{r}_{E C \text { WT }} \text { AT DO FCO2 Zp_den }=-0.327 \text { in S3 }
\end{aligned}
$$

This contradictory finding on the influence of AT and WT on Ec possibly resulted from the fact that the frog species passes, being a lung breather, most of the day on littoral vegetation of water bodies (Lalremsanga 2012), hence is reasonably more influenced by AT than WT. The insignificance of WT on Ec could also, possibly, have resulted due to the basic fact that diurnal water temperature varies comparatively much lesser than that of AT. However, the equations ( $\mathbf{r}_{E c \text { WT }}$ AT DO FCO2 Z Z_den $=-0.469 ; \mathbf{r}_{E c \text { WT• AT FCO2 Z Z_den }}=-0.602^{*} ; \mathbf{r}_{E c}$ WT• AT $\left.\mathrm{DO} \mathrm{FCO}_{2}=-0.669^{* *}\right)$ for $\mathrm{S} 1$, where the influence of WT on Ec was significant (negative), indicate the result of factor interactions in the ecosystem.

The influence of dissolved oxygen on Ec was not significant at any of the sites (Table 1). This is consistent with the fact that Ec is a lung breather and the present work was based on only adult frogs. It, however, should be mentioned here that the density of $E c$ was highest, among all the sites, at S2 which had the highest concentration of DO (Table 1). Khan et al. (2012), Chowdhury and Das (2014) and Akram et al. (2015) pointed out the influence of DO on the population change of Ec. Presently, with total data, the influence of DO was not significant at any of the sites. However, analysis with only the summer data, when peak abundance was obtained, shows significance $(\mathrm{p}<0.001)$ of DO at two of the sites. The increase of Ec in March to April, could have been the result of breeding in late winter (February 2014) after the first showers $(200 \mathrm{~mm}$ of rainfall in February; Bangladesh Meteorological Department), and the time period required for the larval metamorphosis to young frogs. Similarly, $\mathrm{FCO}_{2}$ was also not a very influential factor as it was found to have significant influence on Ec at S3 only.

Like $\mathrm{FCO}_{2}$, zoo plankton density had also little influence on Ec. The correlation was significant only at S1, where frog density was the least (Table 1). This observation is consistent with the fact that the present work dealt with only the adult frogs, at which stage of life the species is a predacious one (MohantyHejmadi and Acharya 1979, Das and Coe 1994). Earlier workers (Das 1994; Khan 2000) reported that the tadpoles of Ec are mainly organic matter and benthic feeders (Khan and Mufti 1995). Hence, the only significant relationship obtained at S1 appears to be not generally indicative, and could have been a stray incidence of the effect of factor interactions.

Summarizing, each of pond functioned as a separate system. Of the nine abiotic and biotic factors included in the analyses, only four (three abiotic and one biotic), viz., AT, WT, $\mathrm{FCO}_{2}$ and $\mathrm{Zp}$ _den, were found to have some, at least in one of the three ponds, influence on Ec. AT had significant influence in all the three ponds (maximum $54 \%$ at $\mathrm{S} 2, \quad \mathbf{r}=0.737^{* *}$, Table 1 ). The influence of AT on 
Ec has also been recognized by other workers (Boulenger, 1920; Dutta and Mohanty-Hejmadi 1976, Jangir 2005). The other three, viz., WT, $\mathrm{FCO}_{2}$ and Zp_den, were significant only each at one of the three ponds - 39, 31 and 44\% in $\mathrm{S} 2, \mathrm{~S} 3$ and S1, respectively (Table 1). The following pairs of equations show the variable nature of the influences of these factors on $E c$, and the phenomenon of factor interactions in ecosystem.

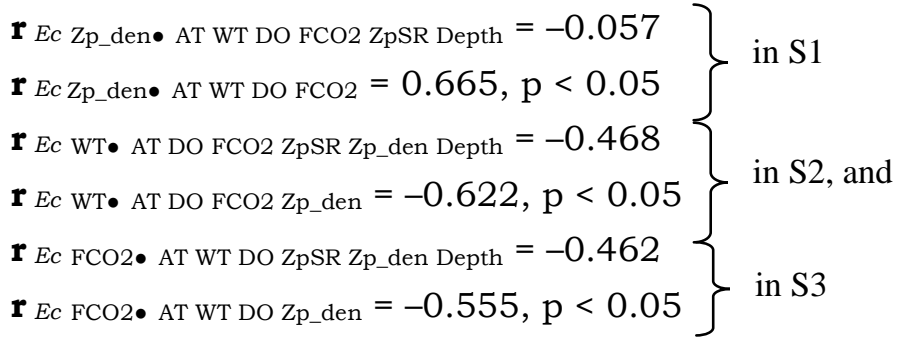

The following workers recorded the influences of the above mentioned factors; for instance, Khan and Malik (1987), Jangir (2005), Lalremsanga (2012) and Narzary and Bordoloi (2012) mentioned the influence of WT, and that of $\mathrm{FCO}_{2}$ by Shaikh et al. (2014) and Narzary and Bordoloi (2012). The influence $\left(\mathrm{r}^{2}\right.$ $=44 \%$ ), though only at $\mathrm{S} 1$, of $Z \mathrm{p} \_$den on $E c$ is an interesting finding of the present work. No earlier works recorded the inclusion of zooplankton in the food menu of adult Ec. The matter deserves special attention in future works. Chowdhury and Das (2014) reported the influence of DO, WpH and Depth on Ec. Their work was on five sites (one rice field, three ditches, and one pond), and on only for the winter season. The difference in the two findings might have cropped up from the facts that the former work was based on analyses with total data of all the sites (not separately), that the present work included data of the other two seasons (summer and rainy season), and that presently the data analyses were done separately for the ponds. This suggestion finds support in the observation of Rittenhouse (2007) and Lemckert et al. (2006) - the habitat selections can be changed with environmental conditions. Though DO was found to be influential in the ecology of Ec by Khan et al. (2012) and Akram et al. (2015), it was not at all an influential factor, as explained earlier, in any of the three present sites. The highest total influence of the abiotic and biotic factors, included in the present work, on Ec was 69\% (Table 1), which indicates that further study on the of $E c$ should be widened incorporating other related ecological factors.

\section{CONCLUSION}

Of the presently investigated abiotic and biotic factors, viz., AT, WT, DO, $\mathrm{FCO}_{2}, \mathrm{ZSR}, \mathrm{Zp}$ _den, size, depth, and PSR, AT appeared to have relatively more influence on the density, abundance, biological activity, and overall ecology of 
Ec. This observation needs to be further investigated undertaking a work on more and much diversified water bodies inhabited by $E c$.

\section{LITERATURE CITED}

AHMED, N. 1968. Geography of East Pakistan. Oxford Univ. Press, Oxford. pp. 401.

AKRAM, A., RAIS, M., ASADI, M.A., JILANI, M.J., BALOUCH, S., ANWAR, M. and SALEEM, A. 2015. Do habitat variables correlate anuran abundance in arid terrain of Rawalpindi-Islamabad areas, Pakistan? J. of King Saud Univ. Science, http://dx.doi.org/10.1016/j.jksus.2015.02.001.

ALAM, M.S., IGAWA, T., KHAN, M.M.R., ISLAM, M.M., KURAMOTO, M., MATSUI, M., KURABAYASHI, A. and SUMIDA, M. 2008. Genetic divergence and evolutionary relationships in six species of genera Hoplobatrachus and Euphlyctis (Amphibia: Anura) from Bangladesh and other Asian countries revealed by mitochondrial gene sequences. Mole Phyl and Evol. 48: 515527.

ASMAT, G.S.M. and HANNAN, M.A. 2007. Checklist of Wild Animals of Bangladesh, Gazi Publishers, Dhaka. 292 pp.

ALFORD, R.A. and RICHARDS, S.J. 1999. Global amphibian declines: a problem in applied ecology. Ann. Rev. Eco. and System 30: 133-165.

APHA, 2005. Standard Methods for the Examination of Water and Waste Water. 21st Edn., Washington, D.C.

ASIH (American Society of Ichthyologists and Herpetologists). 2004. Guidelines for use of Live Amphibians and Reptiles in Field and Laboratory Research. Second edition, revised by the Herpetological Animal Care and Use Committee (Beaupre, S.J., Jacobson, E.R., Lillywhite, H.B., and Zamudio, K.R. eds.). Available online at <http://www.asih.org/pubs> (accessed 1 March 2015).

BAlletTO, E., CHERCHI, M.A. and GASPERETTI, J. 1985. Amphibians of the Arabian Peninsula. Fauna Saudi Arabia 7: 318-392.

BANKS, B. and BEEBEE, T.J.C. 1987. Factors influencing breeding site choice by the pioneering amphibian Bufo calamita. Holarctic Ecol. 10: 14-21.

BLAUSTEIN, A.R. and KIESECKER, J.M. 2002. Complexity in conservation: lessons from the global decline of amphibian populations. Ecol. Lett. 5: 597-608.

BLAUSTEIN, A.R., WAKE, D.B. and SOUSA, W.P. 1994. Amphibian declines: judging stability, persistence and susceptibility of populations to local and global extinctions. Cons. Biol. 8: 60-71.

BOULENGER, G.A. 1890. The Fauna of British India Including Ceylon and Burma, Reptilia and Batrachia. Taylor and Francis, London. 450 pp.

BOULENGER, G.A. 1920. A monograph of the south Asian, Papuan, Melanesian and Australian frogs of the genus Rana. Rec. Indian Mus. Calcutta 20: 1-226.

CHAKMA, S. 2009. Euphlyctis cyanophlyctis. In: Kabir, S.M.H., Ahmed, A.T.A., Rahman, A.K.A., Ahmed, Z.U., Begum, Z.N.T., Hassan, M.A., and Khondker, M. (eds.) 2009. Encyclopedia of Flora and Fauna of Bangladesh, Vol. 25. Amphibiansn and Retiles. Asiatic society of Bangladesh, Dhaka. pp. 9-10.

CHOWDHURY, M.A.W. 2009. Acoustic Analysis of the Amphibian Species Diversity in Chittagong Region. M. Phil. Thesis (unpublished). University of Chittagong. 220 pp. 
CHOWDHURY, M.A.W. and DAS, M.C. 2014. Habitat Selection and Population Ecology of Six Winter Active Anurans (Class: Amphibia) of The Chittagong University Campus. Bangladesh J. Environ. Sci. 26: 67-74.

CRUMP, M.L. 1991. Choice of oviposition site and egg load assessment by a tree frog. Herpetologica 47: 308-315.

DAS, A. 2008. Diversity and Distribution of Herpetofauna and Evaluation of their Conservation Status in the Barail Hill Range (including the Barail Wildlife Sanctuary) Assam, Northeast India. Final Report: Barail Herpetofauna Project, Aaranyak. 94 pp.

DAS, M.C. 2013. Status and Habitat Preference Analysis of Some Winter Breeder Frogs at Chittagong University Campus, B. Sc. (Hons). project paper (unpublished), Department of Zoology, University of Chittagong.

DAS, I. 1994. The internal oral morphology of some anuran larvae from south India: a scanning electron microscopic study. Amphibia-Reptilia 15: 249-256.

DAS, I. and COE, M. 1994. The dental morphology and diet in anuran amphibians from south India. J. Zool. Lond. 233: 417-427.

DAS, I., and DUTTA, S.K. 1998. Checklist of the amphibians of India, with English common names. Hamadryad 23: 63-68.

DANIELS, R.J.R. 1992. Geographical distribution patterns of amphibians in the Western Ghats, India. J. Biogeo. 19: 521-529.

DANIEL, J.C. 2002. The Book of Indian Reptiles and Amphibians. Bombay Natural History Society, Mumbai. p.198.

Declining Amphibian Population Task Force (DAPTF), 2001, Tim Halliday (Director). The Open University,

UK: http://www.open.ac.uk/OU/Academic/Biology/J_Baker/JBtxt.htm

DUBOIS, A. and OHLER, A. 1995. Frogs of the subgenus Pelophylax (Amphibia, Anura, genus Rana). Zoologica Poloniae 39: 139-204.

DUTTA, S.K. and MOHANTY-HEJMADI, P. 1976. Breeding and life history of the Indian bull frog Rana tigerina (Daudin). Prakruti Utkal Univ. J. Sci. 13(1\&3): 51-59.

FORD, L.S. and CANNATELLA, D.C. 1993. The major clades of frogs. Herpet Monog. 7: 94-117.

GASTON, K.J., BLACKBURN, T.M. and LAWTON, J.H. 1997. Interspecific abundance range size relationships: an appraisal of mechanisms. J. Anim. Ecol. 66: 579-601.

GIBBONS, J.W., SCOTT, D.E., RYAN, T.J., BUHLMANN, K.A., TUBERVILLE, T.D., METTS, VB.S., GREENE, J.L., MILLS, T., LEIDEN, Y., POPPY, S. and WINNE, C.T. 2000. The global decline of reptiles, déjà vu amphibians. Bioscience 50: 653-666.

GÜNTHER, A.C.L.G. 1864. The Reptiles of British India. Arment Biological Press. 550 pp.

HASAN, M.K., Khan, M.M.H. and Feeroz, M.M. 2014. Amphibians and Reptiles of Bangladesh - A Field Guide. Arannayk Foundation, Dhaka, Bangladesh.

HARTEL, T.L. DEMETER, D. COGALNICEANU and TUlBURE, M. 2006. The influence of habitat characteristics on amphibian species richness in two river basins of Romania. In: Proceedings of the $13^{\text {th }}$ Congress of the Societas Europaea Herpetologica. pp. 47-50.

INDERMAUR, L., WINZELER, T., SCHMID, B.R., TOCKNER, K. and SCHAUB, M. 2009. Differential resource selection within shared habitat types across spatial scales in sympatric toads. Ecology 90: 3430-3444. 
INGER, R.F. 1999. Distribution of Amphibians in Southern Asia and adjacent Islands. In: Patterns of Distribution of Amphibians: A Global Perspective (Duellman, W. E. ed.). John Hopkin Univ. Press, Baltimore and London. pp. 445-482.

ISLAM, A.T.M., CHOWDHURY, M.S., HOQUE, A.K.M.M. and MALEK, S.A. 1979. Detailed Soil Survey Chittagong University Campus. Department of soil Survey. 208 pp.

JANGIR, O.P. 2005. Developmental Biology: A Manual. Published by Agrobios (India). Vinay Offset Press, Jodhpur.

JOSHY, S.H., ALAM, M.S., KURABAYASHI, A., SUMIDA, M. and KURAMOTO, M. 2009. Two new species of the genus Euphlyctis (Anura: Ranidae) from southwestern India, revealed by molecular and morphological comparisons. Alytes. 26(1-4): 97-116.

KABIR, S.M.H., AHMED, A.T.A., RAHMAN, A.K.A., AHMED, Z.U., BEGUM, Z.N.T., HASSAN, M.A. and KHONDKER, M. (eds.). 2009. Encyclopedia of Flora and Fauna of Bangladesh, Vol. 25. Amphibians. Asiatic society of Bangladesh, Dhaka. 204 pp.

KHAN, M.S. and MALIK, S.A. 1987. Reproductive strategies in a subtropical anuran population in arid Punjab, Pakistan. Biologia (Lahore) 33: 279-303.

KHAN, M.S. 1997. A new subspecies of common skittering frog Euphlyctis cyanophlyctis (Schneider, 1799) from Balochistan, Pakistan. Pak. J. Zool. 29(2): 107-112.

KHAN, M.S. 2000. Buccopharyngeal morphology and feeding ecology of Microhyla ornata tadpoles. Asiatic Herpetological Resear. 9: 130-138.

KHAN, M.S. and MUFTI, S.A. 1995. Oropharyngeal morphology of detritivorous tadpole of Rana cyanophlyctis Schneider, and its ecological correlates. Pak. J. Zool. 27: 43-49.

KHAN, M.A.G., NATH, S.K., SADIQUE, S.B. and BISWAS, S.C. 2007. Limnological conditions of three ponds and ecology of their macrobenthetic invertibrates. Bangladesh J. Zool. 35(1): 1-17.

KHAN, M.Z., BEGUM, A., GHALIB, S.A., KHAN, A.R., YASMEEN, R., SIDDIQUI, T.F., ZEHRA, A., ABBAS, D., TABASSUM, F., SIDDIQUI, S., JABEEN, T and HUSSAIN, B. 2012. Effects of Environmental Pollutants on Aquatic Vertebrate Biodiversity and Inventory of Hub Dam: Ramsar Site. Canadian J. Pure and Applied Sci. 6(2): 1913-1935.

LALREMSANGA, H.T. 2012. Studies on the Ecology, Breeding Behavior and Development of Ranid and Microhylid Anurans Prevalent in Mizoram, Northeast India. Ph. D. thesis (unpublished). North Eastern Hill University, Shillong, India. 282 pp.

LEMCKERT, F. HAYWOOD, A. BRASSIL, T. MAHNONY, M. 2006. Correlations between frogs and pond attributes in central New South Wales, Australia: What makes a good pond? Applied Herp. 3: $67-81$.

LIN, Y.S., LEHTINEN, R.M. and KAM, Y.C. 2008. Time-dependent oviposition site selection of a phytotelm-breeding and egg-provisioning frog (Kurixalus eiffingeri) in relation to habitat characteristics and conspecific cues. Herpetologica 63: 413-421.

LIPS, K.R., REASER, J.K., YOUNG, B.E. and IBANEZ, R. 2001. Amphibian Monitoring in Latin America: A Protocol Manual. Herpetological Circular No. 30, Society for the study of Amphibians and Reptiles. xi+115 pp.

MARSH, D.M. FEGRAUS, E.H. and HARRISON, S. 1999. Effect of breeding pond isolation on the spatial and temporal dynamics of ponds use by the tungara frog, Physalaemus pustulosus. J. Anim. Ecol. 68: 804-814.

MOHANTY-HEJMADI, P. and ACHARYA, B.K. 1979. Observations on food habits of six species of Indian frogs. J. Bombay Nat. Hist. Soc. 76: 291-296. 
NARZARY, J. and BORDOLOI, S. 2012. A study on certain common pond breeding anurans and their tadpoles in a pond of western Assam, India. Int. J. Adv. Bio. Res. 2(2): 342-348.

NIE, M., CRIM, J.D. and ULTSCH, G.R. 1999. Dissolved Oxygen, Temperature, and habitat selection by bullfrog (Rana catesbeiana) tadpoles. Copeia pp. 153-162.

POPE, S.E. FAHRIG, L. and MERRIAM, H.G. 2000. Landscape complementation and met population effects on Leopard Frog populations. Ecology 81: 2498-2508.

POUGH, F.H. 2004. Herpetology, $3^{\text {rd }}$ edition. Pearson Prentice Hall, Upper Saddle River, NJ.

PYRON, M. 1999. Relationships between geographical range size, body size, local abundance, and habitat breadth in North American suckers and sunfishes. J. Biogeography 26: 549-558.

RITTENHOOUSE, T.A.G. 2007. Behavioral choice and demographic consequences of wood frog habitat selection in response to land use. A Ph.D. thesis (unpublished). $139 \mathrm{pp}$.

SHAIKH, K., GACHAL, G.S., MEMON, S.Q., SODHO, N.A. and SHAIKH, M.Y. 2014. Assessment of amphibian environment through Physico chemical analysis in Pakistan. J. Biodi. and Env. Sci. 5(3): 255-261.

SHARMA, R.C. and KUMAR, K. 2002. Conservation and management of lakes of Garhwal, Himalaya. In: Ecology and Conservation of Lakes, Reservoir and Rivers. ABD publishers, Jaipur. India 2: $562-580$

SHIL, S.R. 2014. Analysis of Habitat Preference of Some Anurans (Family: Dicroglossidae) of the Chittagong University Campus, Chittagong. M.S. project paper (unpublished), Department of Zoology, University of Chittagong.

STUART, S. N. CHANSON. J.S. COX, N.A. YOUNG, B.E. RODRIGUES, A.S.L. FISCHMAN, D.L. and WALLER, R.W. 2004. Status and trends of amphibian declines and extinctions worldwide. Science 306: 1783-1786.

UNESCO/WHO. 1978. Water Quality Survey. Studies and Reports in Hydrology. No. 23. Paris: United Nation Educational Scientific and Cultural Organization and World Health Organization.

WETZEL, R.G. 1975. Limnology. W.B. Saunders Company, London. 450 pp.

http://www.bmd.gov.bd/?/home/Bangladesh Meteorological Department. Accessed on 19-03-2015. 